\title{
FISCAL FATIGUE AND PUBLIC DEBT LIMIT IN BRAZIL: ARE WE ON SUSTAINABLE PATH?
}

0

Rodrigo Mendes Pereira
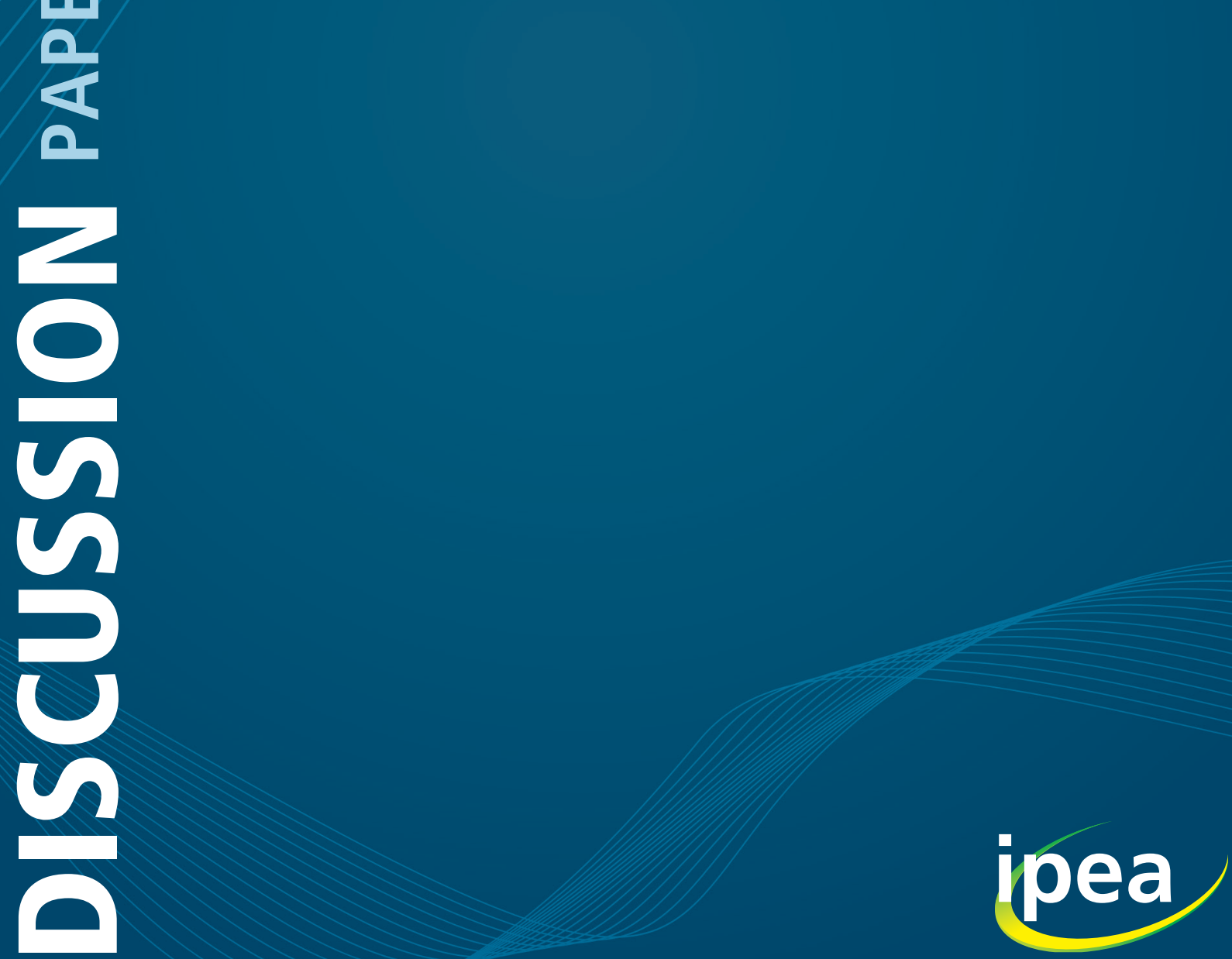



\section{DISCUSSION PAPER}

Brasilia, August 2020

FISCAL FATIGUE AND PUBLIC DEBT LIMIT IN BRAZIL:

ARE WE ON SUSTAINABLE PATH?

Rodrigo Mendes Pereira'

1. Researcher at the Department of Macroeconomic Policies and Studies (Dimac) of Ipea. E-mail: <rodrigo.pereira@ ipea.gov.br>. 


\section{Federal Government of Brazil}

Ministry of Economy

Minister Paulo Guedes

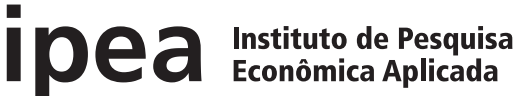

A public foundation affiliated to the Ministry of Economy, Ipea provides technical and institutional support to government actions - enabling the formulation of numerous public policies and programs for Brazilian development and makes research and studies conducted by its staff available to society.

\section{President}

Carlos von Doellinger

Director of Institutional Development

Manoel Rodrigues Junior

Director of Studies and Policies of the State,

Institutions and Democracy

Flávia de Holanda Schmidt

Director of Macroeconomic Studies and Policies José Ronaldo de Castro Souza Júnior

Director of Regional, Urban and Environmental Studies and Policies

Nilo Luiz Saccaro Júnior

Director of Sectoral Studies and Policies of Innovation and Infrastructure

André Tortato Rauen

Director of Social Studies and Policies

Lenita Maria Turchi

Director of International Studies, Political and

Economic Relations

Ivan Tiago Machado Oliveira

Head of Press and Communication

Mylena Fiori

Ombudsman: http://www.ipea.gov.br/Ouvidoria

URL: http://www.ipea.gov.br

\section{DISCUSSION PAPER}

\begin{abstract}
A publication to disseminate the findings of research directly or indirectly conducted by the Institute for Applied Economic Research (Ipea). Due to their relevance, they provide information to specialists and encourage contributions.
\end{abstract}

(C) Institute for Applied Economic Research - ipea 2020

Discussion paper / Institute for Applied Economic Research.- Brasília : Rio de Janeiro : Ipea, 1990-

ISSN 1415-4765

1. Brazil. 2. Economic Aspects. 3. Social Aspects. I. Institute for Applied Economic Research.

CDD 330.908

Ipea publications are available for free download in PDF (all) and EPUB (books and periodicals).

Access: http://www.ipea.gov.br/portal/publicacoes

The opinions expressed in this publication are of exclusive responsibility of the authors, not necessarily expressing the official views of the Institute for Applied Economic Research and the Ministry of Economy.

Reproduction of this text and the data contained within is allowed as long as the source is cited. Reproduction for commercial purposes is prohibited. 


\section{CONTENTS}

ABSTRACT

SINOPSE

1 INTRODUCTION

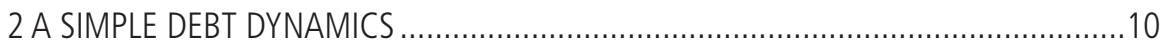

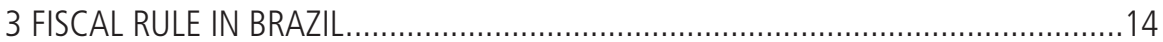

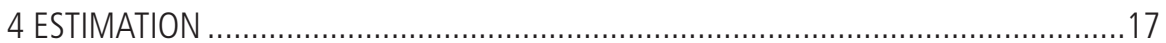

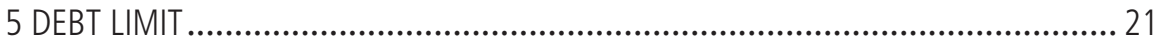

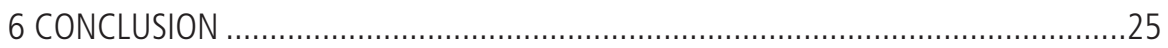

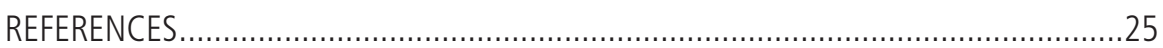

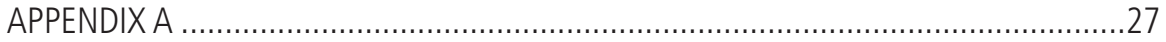





\section{ABSTRACT}

In this paper I use Ghosh et al. (2013) approach to assess Brazil's fiscal sustainability, fiscal fatigue, and public debt limit. Using monthly data for the last 21 years, I estimate Brazil's fiscal reaction function and an eventual fiscal fatigue effect, which is a lack of government's will (or capability) to implement higher primary surpluses as a reaction to higher levels of debt. I show that fiscal fatigue occurs at relatively mild levels of debt in Brazil. I also define Brazil's debt limit, which is the precise level of debt/GDP ratio above which the debt dynamics becomes explosive, public debt becomes unpayable, and the government invariably defaults. I show that the debt limit in Brazil is much lower than the limits that have been estimated for advanced economies.

Keywords: primary balance; debt/GDP ratio; fiscal fatigue; debt limit.

\section{SINOPSE}

Neste artigo, eu uso a abordagem de Ghosh et al. (2013) para investigar a sustentabilidade fiscal no Brasil, a fadiga fiscal e o limite para a dívida pública. Usando dados mensais para os últimos 21 anos, estimo a função de reação fiscal brasileira e um eventual efeito de fadiga fiscal, que é a falta de vontade (ou de habilidade) do governo para implementar um resultado primário mais alto, como reação a um aumento no endividamento. Mostro que a fadiga fiscal ocorre em níveis relativamente baixos de dívida no Brasil. Também defino o limite da dívida pública brasileira, que é o nível preciso da razão dívida/PIB, acima do qual a dinâmica da dívida se torna explosiva, tornando-a impagável, o que ocasiona invariavelmente a aplicação de uma moratória, por parte do governo, sobre ela. Por fim, mostro que o limite da dívida no Brasil é muito menor que aqueles que têm sido estimados para economias desenvolvidas.

Palavras-chave: resultado primário; razão dívida/PIB; fadiga fiscal; limite da dívida. 



\section{Discussion}

Paper

250 Fiscal Fatigue and Public Debt Limit in Brazil: are we on sustainable path?

\section{INTRODUCTION}

One of the key challenges for the Brazilian economy today is to produce a fiscal adjustment large enough to revert the alarming trajectory of its debt/GDP ratio. Large tax cuts granted to strategical sectors of the economy not only did not have the desired effect in terms of economic growth, but also transformed a decade-long general government primary surplus of nearly 3 percent of GDP into a deficit (see graph 1 ). The large recession that hit the economy in 2015/2016 only made things worse. As a result, in a period of roughly five years, from 2014 to 2019, the net debt/GDP ratio nearly doubled in Brazil, from 30 to 60 percent. Brazil's public debt is now the highest among developing economies in the world, raising concerns about its sustainability.

GRAPH 1

Brazilian general government public net debt and primary balance, as shares of GDP (1998-2019)

$1 \mathrm{~A}-$ Net public debt

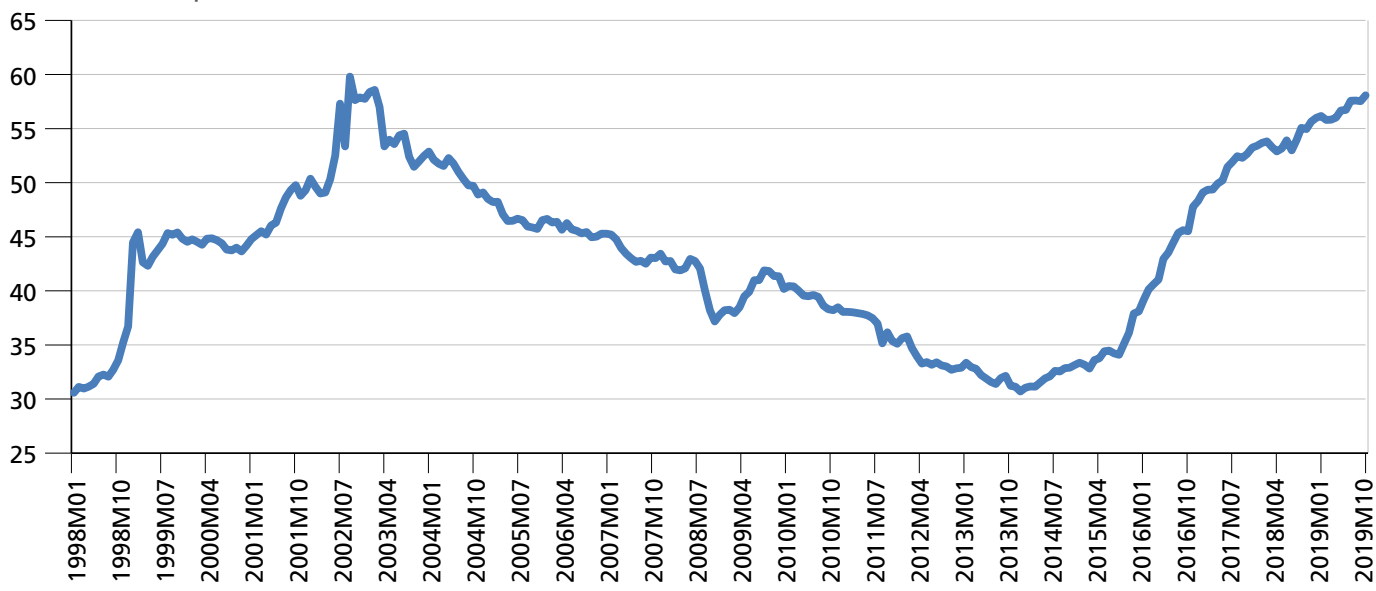




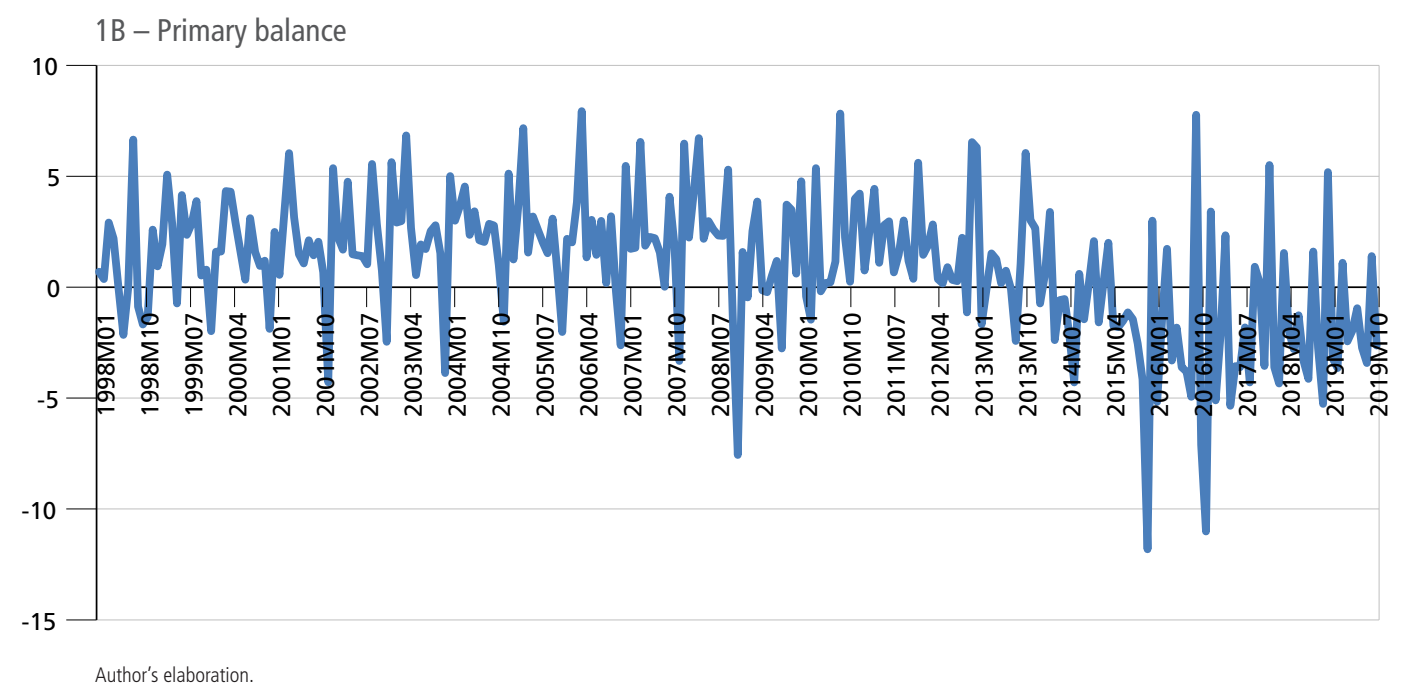

Earlier works on fiscal sustainability have relied on the concept of an intertemporal budget constraint: the debt level today has to be equivalent to the expected present value of future primary surpluses. Hamilton and Flavin (1986) test for a speculative bubble in the US debt for the period 1960 to 1984 . Their idea was to run a regression of the US debt on an exponential term $(1+r)^{n}$, where $\mathrm{r}$ is the interest rate. A significant coefficient for that term would indicate a bubble. They did not find evidence of such bubble. Trehan and Walsh $(1988 ; 1991)$ propose methods to test the constraint that are based on unit root and cointegration properties of fiscal time series. They show that the intertemporal budget constraint is satisfied when primary surplus and debt cointegrate with a cointegration vector $(1,-r)$ (Trehan and Walsh, 1988).

Bohn (2007) shows that Trehan and Walsh's stationarity/cointegration criteria is equivalent to having an arbitrarily high (but finite) order of differences on the debtGDP ratio that is stationary. And that is always met by the data. The author then proposes an alternative approach to assess fiscal solvency based on the behavioral response of the primary result to lagged public debt. Bohn (2008) shows that sustainability can be tested by estimating a policy rule (reaction function) for the primary balance as a share of GDP, relating it to the debt/GDP ratio. He calls it a "model based debt sustainability analysis". A sufficient condition for debt sustainability is that the primary result always reacts positively to lagged debt (Bohn, 1998; 2008). Bohn considers a linear rule between these variables. This hypothesis is relaxed by Ghosh et al. (2013). These authors show, for a panel of 23 advanced economies and 28 years, that a fiscal rule 
relating primary balances to lagged debt looks a lot more like the shape of an $S$ than with something linear. So the rule is initially convex, turning into concave as the level of indebtedness increases. That $S$ shape brings about new concepts into the analysis. The concavity at higher levels of debt highlights the idea of a fiscal fatigue. A situation in which the primary surplus will not be raised as fast as interest payments with an increasing indebtedness level. ${ }^{1}$ Another implication of the $S$-shaped fiscal rule is that once fiscal fatigue kicks in, there must be a level of debt above which the debt dynamics becomes explosive, and the government defaults. This concept is named by the authors as the debt limit. Default occurs if this level of debt/GDP ratio is reached.

In this paper I use Brazilian time series fiscal data to estimate a fiscal rule. With a number of different econometric specifications, I find that Brazil's fiscal rule is nonlinear. However, it does not always have an $S$ shape, like the countries investigated by Ghosh et al. (2013) In some specifications, a reversed U-shape is a better description of the Brazilian fiscal reaction. Its concavity at the entire range of debts observed in the last 21 years implies that the fiscal fatigue effect shows up at low levels of debt in Brazil. For all the econometric specifications there is a low-debt stable equilibrium, and a high-debt unstable equilibrium, which is also the debt limit of the economy. Moreover, for a number of combinations of interest rate, economic growth, and econometric specifications, I estimate the correspondent debt limit. Those limits are typically within the 60 to 80 percent debt ratio, much lower than the debt limits of 150 to 250 percent of GDP found by Ghosh et al. (2013) to developed economies. Current levels of public debt in Brazil are on an upward trajectory, approaching 60 percent of GDP. They are getting closer to the debt limits estimated here, giving the recovery of fiscal performance a sense of urgency.

A number of studies have been produced about the sustainability of public debt in Brazil. The earlier ones are based on the ideas outlined by Trehan and Walsh $(1988 ; 1991)$ about the time series properties of revenues, outlays, and the debt. Tanner (1995), Luporini (2000), and Issler and Lima (2000) are some of these works that relied on unit roots and cointegration analysis, all of them concluding that Brazilian public debt was on a sustainable path. More recent studies have assessed debt sustainability in Brazil through the estimation of a fiscal reaction function. For the most part, they focus on the idea that this fiscal reaction changes over

1. And that is assuming a constant interest rate. The situation would only get worse if the possible endogeneity of risk premium on government debt is considered. 
time. Mendonça, Santos and Sachsida (2009) model this feature with a Markov-switching, Simonassi (2013) with structural breaks, Luporini (2015) with a rolling sample window of 12 months, and Campos and Cysne (2019) with Kalman filter, penalized spline smoothing and time-varying cointegration. My paper differs from all of these works in one important aspect. Following Ghosh et al. (2013), I consider the possibility of a non-linear fiscal reaction function for Brazil. Instead of assuming that parameters keep changing constantly, this function captures a common behavior that pervades all administrations through time. The premise is that there exists an instinct of self-preservation that forces good, responsible, fiscal behavior. By doing so, I'm able to observe the fiscal fatigue phenomenon, and establish a debt limit for Brazil.

The rest of the paper is organized as follows. Section 2 describes the dynamics of the debt/GDP ratio. Section 3 describes some idiosyncrasies of a Brazilian fiscal reaction function. Section 4 estimates that function with Brazilian time series data of the last 21 years. Section 5 analyses Brazil's debt limit. Section 6 concludes the paper.

\section{A SIMPLE DEBT DYNAMICS}

On its essence, the government budget identity states that the government deficit is equal to the difference between expenditures and revenues. Expenditures can be financial, the interest payments on the debt, and non-financial, all the other current expenditures. The primary result is the difference between revenues and nonfinancial expenditures. The total government deficit is obtained by subtracting from the interest payments on the debt, the primary result.

$$
d e f_{t}=r D_{t-1}-\text { primres }_{t}
$$

Where $r$ is the interest rate, $D$ the stock of debt, and the primary result is primres $_{t}=T_{t}-G_{t}$. Here $T$ stands for tax revenues and $G$ for current government expenditures. The equation for the debt dynamics is straightforward. The debt in time $t$ is the sum of debt in $t-1$ plus whatever deficit the government has between $t-1$ and $t$.

$$
\Delta D_{t}=r D_{t-1}-\text { primres }_{t}
$$




\section{Discussion}

Paper

In terms of ratios of output equation (2) becomes:

$$
\Delta d_{t}=(r-g) d_{t-1}-x_{t}
$$

Where $d t=D t / Y t$ is the debt - output ratio, $x t=$ primrest $/ Y t$ is the primary result - output ratio, and $g$ is the output growth rate $g=\Delta Y t / Y t$ assumed here as a constant. ${ }^{2}$

According to equation (3), if the primary result is zero, than the debt/GDP ratio grows in consonance with the difference between the interest rate and the economy's growth rate. If $r>g$, then there is a level of primary surplus that keeps the debt/GDP ratio constant. In this type of equilibrium $(r-g) d_{t-1=x t}$ and then $\Delta d_{t}=0$. The key question is how the primary result reacts to the lagged debt, which is referred in the literature as the fiscal rule. If this fiscal rule is linear, a stable equilibrium with a positive and finite level of debt/output requires a fiscal rule with a slope steeper than $r-g$.

In graph 2 the level $d^{*}$ is a stable long-run equilibrium for the debt/GDP ratio. Points along the line $(r-g) d$ are the levels of primary balance necessary to keep the debt/ GDP constant. With that fiscal rule, if $d>d^{*}$, the primary surplus exceeds the magnitude necessary to keep the debt/GDP ratio constant. So $d$ falls until $d^{*}$ is reached. On the other hand, if $d<d^{*}$ then there is not enough primary surplus. The debt/GDP is low, there is no urge to produce a large primary surplus, and then the debt/GDP ratio grows. So $d^{*}$ is a stable equilibrium point for the level of public indebtedness.

The essence of Bohn's (2008) method of "model-based" debt sustainability analysis is to estimate the coefficient relating the primary balance to the debt, which in graph 1 is given by the slope of the fiscal rule. Using US data, Bohn finds a statistically significant, large, positive coefficient that is consistent with sustainability. The author also introduces in the regression the squared deviation of public debt from its mean to test for a potential non-linearity in the primary balance to debt relationship, finding no significant effect. Mendoza and Ostry (2008) apply Bohn's method to a panel of 56 economies, through 35 years. They also test for non-linearities, introducing as regressors terms in the square of cube of deviations of debt from within-country means. They find no evidence of a nonlinearity between the primary result and the debt for their panel of countries.

2. A possible extension of that setup is to consider an endogenous output growth rate, which depends, for example, on government indebtedness. 
GRAPH 2

Debt/GDP dynamics with a linear fiscal rule

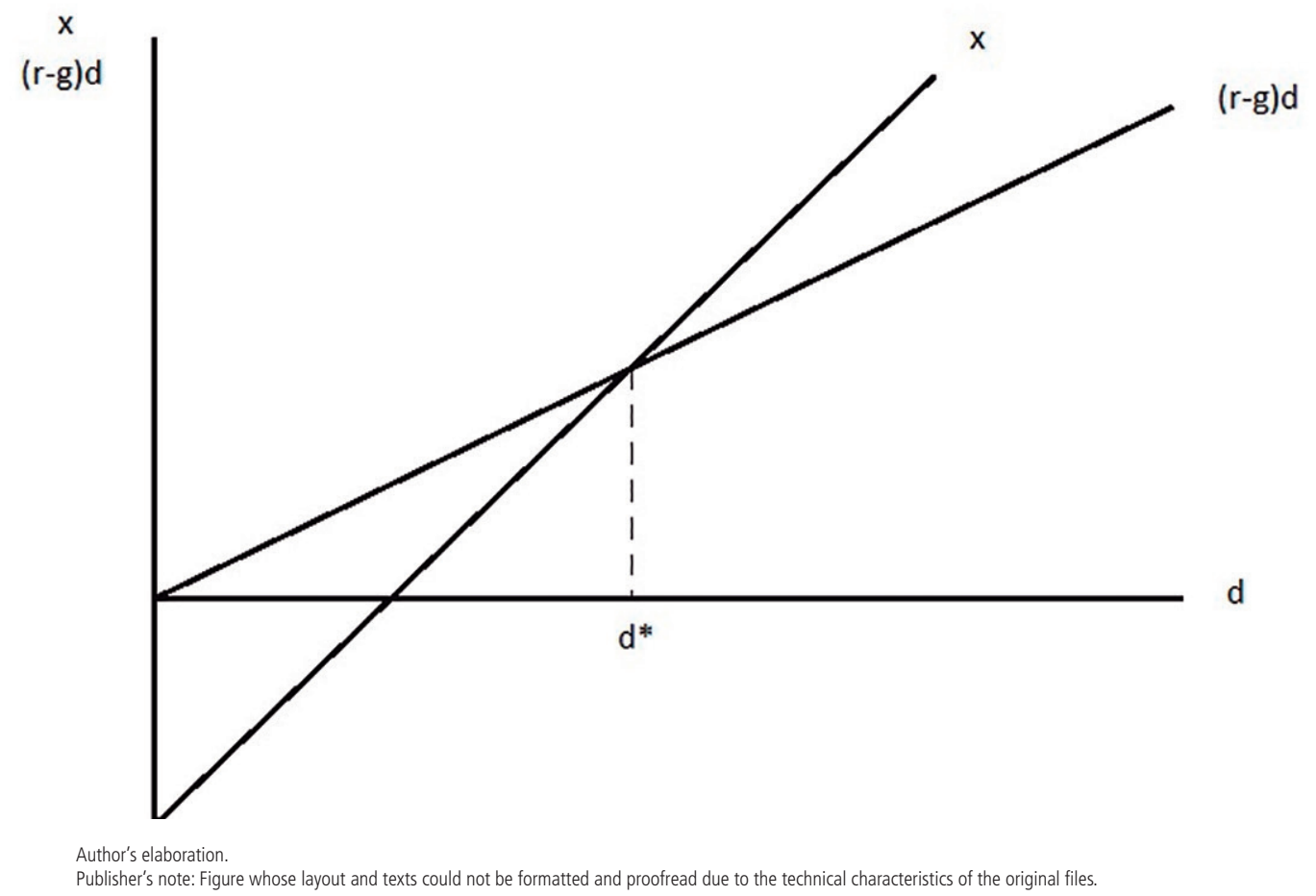

Ghosh et al. (2013) investigate the non-linearity issue a bit further. Their key argument is that at high levels of debt/GDP a country may lose traction on its effort to service the debt. So the government becomes unable (or unwilling) to impose higher fiscal sacrifices to cope with higher interest payments, derived from a higher level of debt. The authors call this effect "fiscal fatigue", and it is represented by a diminishing slope of the fiscal rule, as the debt rises. Intuitively, fiscal fatigue has to occur, sooner or later. Consider an economy with a public debt so high that the magnitude of interest payments necessary to service this debt is larger than the economy's GDP. ${ }^{3}$ Of course, the response of primary balances to debt increases will start to slow down much earlier than that extreme scenario. The fact that fiscal fatigue is not detected in some studies does not mean the phenomenon is not present. Instead, debt levels may not be high enough for the effect to manifest itself. Take a higher amplitude of debts, and fiscal fatigue may appear. Ghosh et al. (2013) investigate a group of 23 advanced economies,

3. The argument here is similar to the tipping point of a Laffer Curve. At the end of the curve we all know that 100 per cent tax rate is not compatible with any tax revenue at all. If 100 percent of your income has to service your debt, than you would rather default. 


\section{Discussion}

Paper

250 Fiscal Fatigue and Public Debt Limit in Brazil: are we on sustainable path?

some of them highly indebted, such as Greece, Italy, and Japan. Sure enough, they find evidence of fiscal fatigue. The coefficients for the square and cubic terms of the debt are all significant, suggesting an "S" shaped fiscal rule, such as the one in graph 3.

In this case $d^{*}$ is still a long-run stable equilibrium for the debt/GDP ratio. It is the first point where the fiscal rule intercepts the line representing combinations of debt/GDP and primary balance that keep the debt/GDP constant. For levels of indebtedness higher than $d^{*}$ the fiscal fatigue effect kicks in, and eventually the two curves intercept again, in what is a debt limit for that economy. The debt limit is an equilibrium, but it is unstable. Any small disturbance that would drive $\mathrm{d}$ above the debt limit would trigger an explosive trajectory for the debt/GDP ratio, and a government default. ${ }^{4}$

GRAPH 3

Debt/GDP dynamics with a cubic fiscal rule

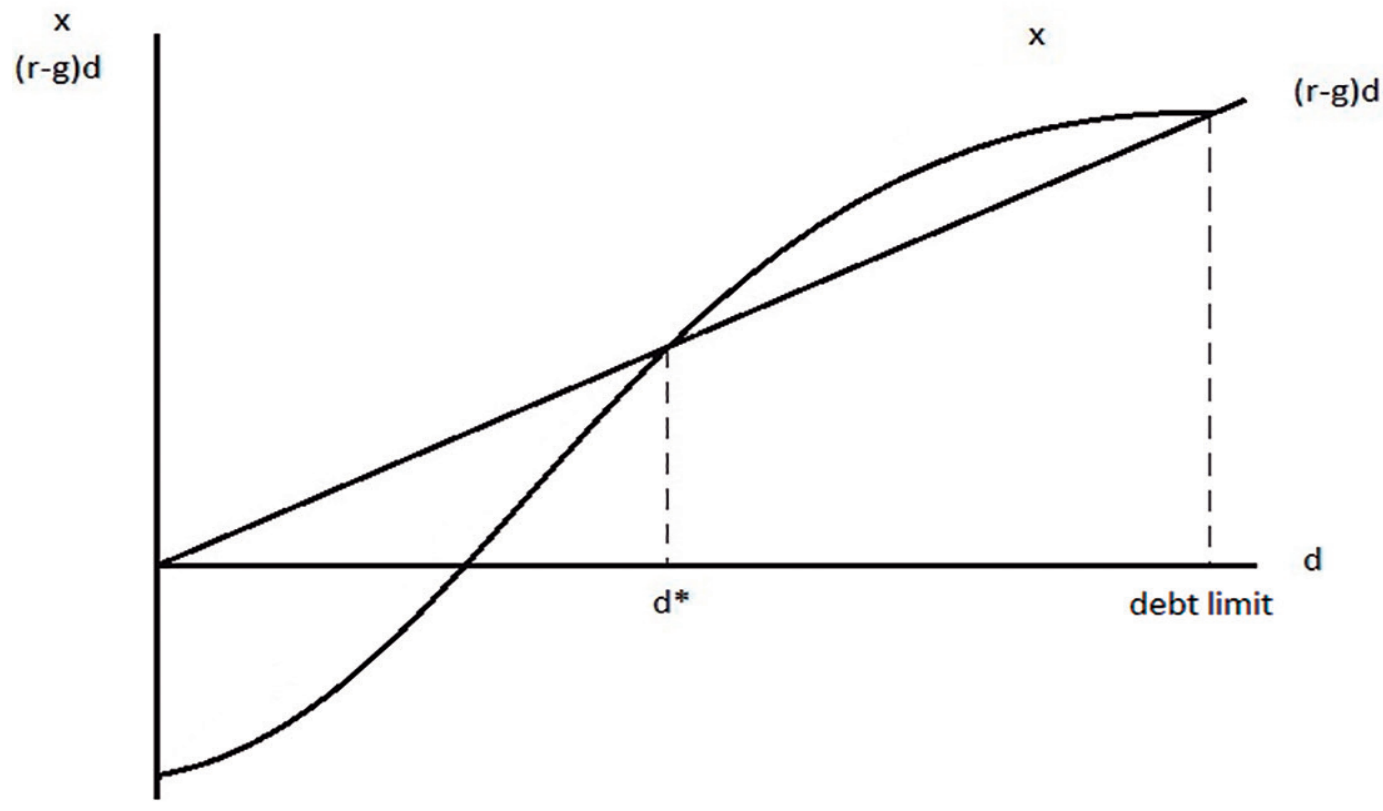

Author's elaboration.

Publisher's note: Figure whose layout and texts could not be formatted and proofread due to the technical characteristics of the original files.

4. Ghosh et al. (2013) also present a stochastic version of this setup with endogenous risk premium and a default probability, in which the debt limit happens at a lower level of $d$ compared to the one in graph 3. That is so because as $d$ gets higher, the probability of default eventually increases so much that no finite interest rate solves the problem, and the straight line of interest payments in graph 3 quickly bends upwards and becomes vertical at a certain level of $d$, smaller than the deterministic debt limit, making the two curves to intercept at that lower $d$. 


\section{FISCAL RULE IN BRAZIL}

In this section I take the Brazilian fiscal data from 1998 to 2019 and I follow Ghosh et al. (2013) theoretical framework to answer a few questions. Is the Brazilian fiscal reaction function linear, does it present an $S$ shape? In case it is non-linear, can I find Brazil's debt limit with the information extracted from the data? Is there any evidence of fiscal fatigue? I take monthly data of Brazil's primary balance and public debt from the country's Central Bank data set (see the appendix for details).

A first piece of evidence can be obtained by a very simple procedure: a scatter plot between the primary balance and the lagged debt. I arbitrarily define brackets of debt/GDP ratios (30 to 34.99 percent, 35 to 39.99 percent, etc.). The data is then sorted on an ascending order, grouped into the brackets, and then for each bracket I take the average debt/GDP ratio and the average of the corresponding primary balances. The debt/GDP is lagged in 12 months. The scatter plot is presented in graph 4 .

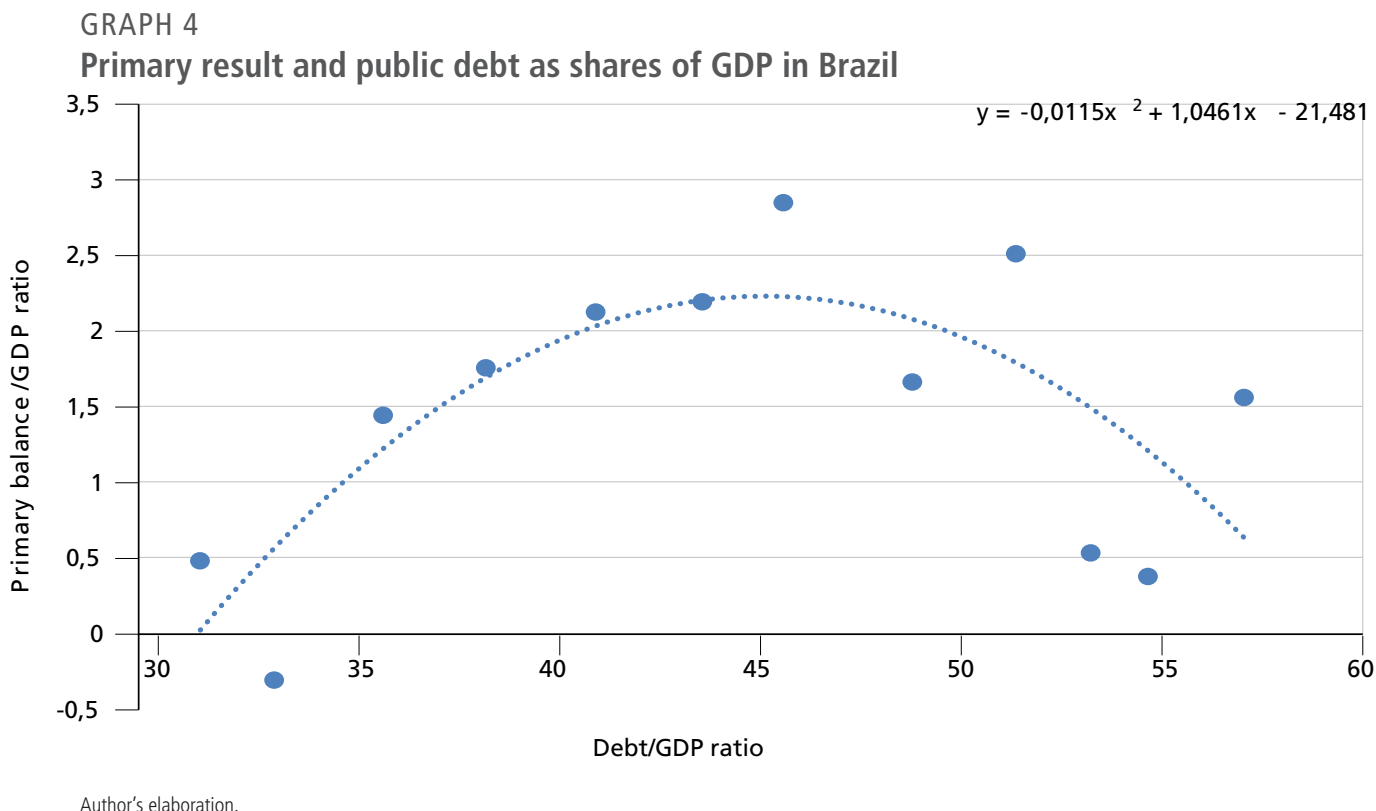

Graph 4 gives the idea of an upside down U-shape for the fiscal rule relating the primary balance and the lagged debt in Brazil. In this simplified scatter plot with 
very few observations, there does not seem to exist a relevant cubic term. ${ }^{5}$ Of course, one cannot rely on a trend line estimated with just a handful of observations, but this procedure works as a good initial guess. In fact, it may be the case that an initial convex region exists in the Brazilian fiscal reaction function, for very low levels of indebtedness, and what is observed is actually the concave portion of a larger S-shaped curve. For one of the regression models outlined in the next section, that $S$-shaped function seems to be a better fit to the data.

If the reaction function is concave throughout the range of debt/GDP ratios observed in the Brazilian economy in the last 21 years, then the fiscal fatigue element is present even at debt/GDP ratios as low as 30,35 percent. When Brazil's public debt increases from low levels, policy makers react with a tighter fiscal policy that generates higher primary surpluses. However, the responsiveness is progressively weaker. Eventually, for higher debt/GDP ratios, the fatigue is so intense that the relationship becomes negative. The primary balance falls in response to a debt increase.

Graph 4 also highlights an important aspect in the Brazilian fiscal rule. The fatigue effect happens at relatively low levels of debt. In contrast, Ghosh et al. (2013) detect fiscal fatigue in a group of advanced economies for levels of debt way over 100 percent of GDP.

This particular fiscal rule has a number of implications for Brazilian fiscal policy. First there seems to be a responsible behavior, in which governments increase the primary result in response to a higher debt. This same fiscal responsible behavior is found by Bohn (2008) for the US economy, and by Mendoza and Ostry (2008) for subsets of advanced and emerging economies. However, in Brazil that behavior is counteracted by the fiscal fatigue, which increases with the debt. Servicing this debt becomes so burdensome as it grows, that policymakers cannot impose the sacrifices that would enhance primary balances and bring the debt down.

A second implication is that just like the $S$-shaped fiscal reaction function, there may be two equilibrium in this Brazilian U-shaped function. Graph 5 presents the dynamics in this case. There is one stable equilibrium $d^{*}$ with low debt, and one unstable

5. In fact, if a cubic term is added in graph 4, its coefficient is so small that the trend line remains essentially the same. 
equilibrium, with higher debt, which is also the debt limit of the economy. Between $d^{*}$ and the debt limit the government runs a primary balance that more than compensates the interest payments, and the debt falls. Below $d^{*}$ and above the debt limit, the primary balance does not keep pace with interest payments, and the debt grows. If the debt/GDP goes beyond the debt limit, the dynamics of the debt becomes explosive, exhausting the tools available to governments in order to stabilize the debt/GDP ratio. In this scenario, unless a shock in the interest rates or in the growth rate of the economy changes the slope of $(r-g) d$, default is inescapable.

Third, the magnitudes on the debt/GDP axis in graph 5 suggest a low debt limit for Brazil, not too distant from the current debt levels. That evidence should raise red flags among Brazilian policymakers. Especially considering that in the real world the perception of an imminent insolvency would raise risk-premiums and interest rates, and default would happen before the fixed-interests debt limit is reached. The next section of the paper estimates the Brazilian fiscal reaction function.

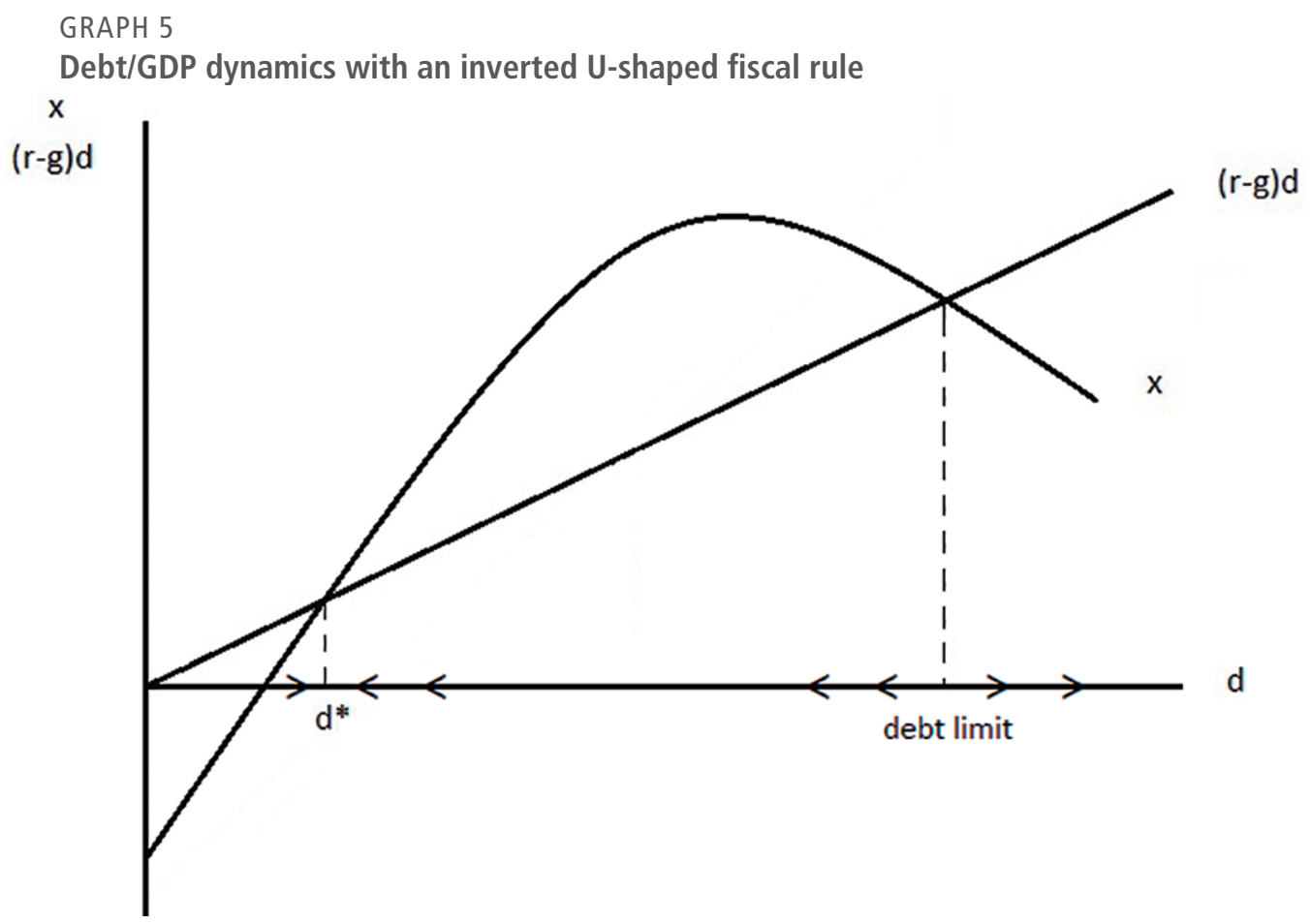

Author's elaboration.

Publisher's note: Figure whose layout and texts could not be formatted and proofread due to the technical characteristics of the original files. 


\section{Discussion}

Paper

\section{ESTIMATION}

In this section I estimate a fiscal rule for Brazil using monthly data for the period from January of 1998 until November of 2019. Appendix 1 describes the data used in the estimation with more details. The dependent variable is the primary balance as a share of GDP. The idea is to estimate a relation with the lagged debt/GDP ratio. I include square and cubic terms to allow for non-linearities. All these terms are based on a 12-month lag of the debt/GDP ratio. Monthly data is typically characterized by intense seasonal effects. So in all regressions I include 11 seasonal dummies. I also include a number of control variables. These variables are the GDP gap, the share of non-earmarked expenditures, trade openness, a number of commodity price indexes, and inflation based on a regular consumer price index. I also introduce a dummy for what is known as Nova Matriz Econômica (New Economic Matrix), which was a big shift in economic policy that took place at the end of the second Lula administration. I consider the beginning of Dilma Rousseff's first term, January 2011, until her impeachment in May 2016 as the period under which this policy was effective. I also include a dummy for whether or not the government was under an IMF agreement.

The first issue in dealing with time series regressions is to make sure that the residuals are stationary, so that the estimates are not spurious. Some of the time series in our data set are clearly non-stationary. Table 1 presents the results of Augmented Dickey-Fuller tests for the presence of unit roots in all the series used in the paper. There is clear evidence of non-stationarity in the primary balance, the debt, and all the different commodity indexes. The output gap, trade openness, share of non-earmarked expenditures and inflation (measured with the IPCA consumer price index) seem to be stationary variables.

An OLS regression with a non-stationary primary balance as dependent variable and some non-stationary regressors can produce non-spurious estimates only when there is some type of cointegration relation between these variables. In that case the residuals will be stationary. After running a number of OLS regressions and observing each group of residuals, I find evidence that the primary balance and the debt alone do not cointegrate, but if we include a price index of metallic commodities (iron ore, etc.) a cointegration relationship becomes apparent. In this case we have stationary residuals. 
TABLE 1

Augmented Dickey-Fuller tests for the presence of unit roots

\begin{tabular}{|c|c|c|c|c|}
\hline & \multicolumn{2}{|c|}{ With a constant } & \multicolumn{2}{|c|}{ With a constant and trend } \\
\hline & $\tau$ stat & $p$ value & $\tau$ stat & $p$ value \\
\hline Primary balance/GDP & -0.61 & 0.866 & -2.74 & 0.218 \\
\hline Debt/GDP & -1.45 & 0.558 & -1.43 & 0.853 \\
\hline Output gap & $-3.178^{* *}$ & 0.0213 & $-3.277^{*}$ & 0.07 \\
\hline Trade openness & $-3.196^{* *}$ & 0.02 & $-3.14^{*}$ & 0.098 \\
\hline Share of non-earmarked expenditures & $-2.868^{* *}$ & 0.049 & -2.924 & 0.155 \\
\hline Inflation & $-3.942^{* * *}$ & 0.0018 & $-4.23^{* * *}$ & 0.004 \\
\hline Commodity price index & -0.382 & 0.91 & -2.575 & 0.292 \\
\hline Commodity price index (Metal) & -0.126 & 0.945 & -2.141 & 0.522 \\
\hline
\end{tabular}

Author's elaboration.

Obs.: 1 . Significance at the $1 \%, 5 \%$ and $10 \%$ levels are denoted by $* * * * *$, and ${ }^{*}$, respectively.

2. Tests use a maximum of 12 lags. Number of lags selected based on the AIC criteria.

The estimation results are presented in table 2 . All the regressions are heteroskedasticity-corrected. The observations are weighted based on their variances in order to get efficient estimates. The first column, Model 1, has only the debt and the square of the debt as regressors. There is a $5 \%$ significance for all coefficients, a low $\mathrm{R}^{2}$, and the $\mathrm{ADF}$ test indicates that the residuals have a unit root. A significant coefficient for the squared debt suggests a non-linear fiscal reaction function, but non-stationary residuals imply a spurious regression. The second column of table 2, Model 2, includes seasonal dummies, improving considerably the predictive power of the model, with an $\mathrm{R}^{2}$ of 0.445 , and statistical significance at the $1 \%$ level for all coefficients. But once again, the presence of non-stationary series and the absence of a cointegration relation imply nonstationary residuals. So, the ADF test suggests that Model 2 is also a spurious regression.

Cointegration begins to appear when the price index of metallic commodities is included as a regressor, along with the output gap, the trade openness, and the share of non-earmarked expenditures. ${ }^{6}$ The estimates are in column 3 . The predictive power of the model is enhanced further, with the regression explaining $74.6 \%$ of the variation observed in the primary result. Significance at the 1 percent level is observed for almost all coefficients (the exception being the 5 percent level of significance of the squared debt

6. A striking characteristic of Brazilian public finances is the large share of earmarked expenditures. The 2020 budget, for example, has 93 percent of expenditures set aside by law. Only 7 percent remains under the discretion of the administration. 
coefficient). Residuals do not have unit roots, implying that the non-stationary variables do cointegrate, the estimates are super-consistent, and the regression is not spurious. The estimated fiscal reaction function has an upside down U shape. In Model 4 I introduce the cubic debt to verify if there is any evidence of a higher polynomial order for the fiscal reaction function. This is always a tricky procedure because quadratic and cubic variables tend to be highly correlated, and the regression may be subject to multicolinearity problems. In fact, the results observed in column 4 suggest the presence of multicolinearity. The colinear regressors (constant, lagged, squared and cubic debts) all lose their statistical significance, and the $\mathrm{R}^{2}$ coefficient remains high. The way to deal with the problem is to remove the colinear regressor, the cubic debt. Then we are back at Model 3.

In Model 5 I introduce the IMF dummy, and then something happens: the coefficient of the cubic debt becomes statistically significant at the 5 percent level. The same thing happens with the lagged and square debt. The multicolinearity problem is no longer noticeable, and the results are acceptable. In this case, the fiscal reaction function has an S-shape, with an initial convex portion for lower debt levels. In Model 6 two more controls are introduced: inflation, and the dummy for the Nova Matriz Economica. None of them seem to be relevant to explain the behavior of the primary balance in Brazil. Their coefficients are not significant at the conventional levels, and the $\mathrm{R}^{2}$ barely moves from the one obtained in Model 5. Model 7 is similar to Model 3, but with a different strategy to remove seasonal effects. Instead of using seasonal dummies in the main regression, the variables that have noticeable seasonal effects are seasonally adjusted, and then used in Model 7. In this case, the seasonal dummies are no longer required, and then are excluded from the estimation. Apart from a lower $\mathrm{R}^{2}$, the results are close to the ones in Model 3.

TABLE 2

Estimation of the fiscal reaction function

\begin{tabular}{lrrrrrrr}
\hline & Model 1 & Model 2 & Model 3 & Model 4 & Model 5 & Model 6 & Model 7 \\
\hline Constant & $-22.39^{* *}$ & $-26.15^{* * *}$ & $-9.47^{* *}$ & -0.70 & $45.17^{*}$ & $54.37^{* *}$ & $-8.31^{* *}$ \\
& $(8.89)$ & -6.104 & $(3.82)$ & $(21.25)$ & $(24.32)$ & $(24.54)$ & $(3.95)$ \\
Lagged debt & $1.07^{* *}$ & $1.006^{* * *}$ & $0.4^{* * *}$ & -0.35 & $-3.363^{* *}$ & $-4.056^{* *}$ & $0.46^{* *}$ \\
& $(0.43)$ & $(0.293)$ & $(0.15)$ & $(1.47)$ & $(1.674)$ & $(1.707)$ & $(0.18)$ \\
Lagged debt - & $-0.012^{* *}$ & $-0.0107^{* * *}$ & $-0.0035^{* *}$ & 0.014 & $0.08^{* *}$ & $0.098^{* *}$ & $-0.0044^{* *}$ \\
square & -0.005 & $(0.0035)$ & $(0.0017)$ & $(0.034)$ & $(0.038)$ & $(0.039)$ & $(0.0021)$ \\
\hline
\end{tabular}




\begin{tabular}{|c|c|c|c|c|c|c|c|}
\hline & Model 1 & Model 2 & Model 3 & Model 4 & Model 5 & Model 6 & Model 7 \\
\hline \multirow[t]{2}{*}{ Lagged debt - cubic } & & & & -0.00013 & $0.0006^{* *}$ & $0.00074^{* *}$ & \\
\hline & & & & $(0.00025)$ & $(0.00028)$ & $(0.00029)$ & \\
\hline \multirow[t]{2}{*}{ Output gap } & & & $0.5^{* * *}$ & $0.508^{* * *}$ & $0.486^{* * *}$ & $0.491^{* * *}$ & $0.56^{\star * \star}$ \\
\hline & & & $(0.064)$ & $(0.065)$ & $(0.063)$ & $(0.06)$ & $(0.077)$ \\
\hline \multirow[t]{2}{*}{ Trade openness } & & & $12.98^{* * *}$ & $14.77^{* * *}$ & $11.28^{* *}$ & $9.638^{* *}$ & $11.35^{* *}$ \\
\hline & & & $(4.55)$ & $(4.80)$ & (4.51) & (4.536) & $(5.76)$ \\
\hline \multirow{3}{*}{$\begin{array}{l}\text { Share of non- } \\
\text { earmarked expen- } \\
\text { ditures }\end{array}$} & & & & & & & \\
\hline & & & & & & & \\
\hline & & & (6.29) & $(6.25)$ & (6.346) & $(6.277)$ & $(6.11)$ \\
\hline \multirow[t]{2}{*}{ IMF Dummy } & & & & & $-1.33^{* * *}$ & $-1.19^{* * *}$ & \\
\hline & & & & & $(0.393)$ & $(0.438)$ & \\
\hline \multirow[t]{2}{*}{ Inflation } & & & & & & 0.054 & \\
\hline & & & & & & $(0.29)$ & \\
\hline \multirow[t]{2}{*}{ NME Dummy } & & & & & & 0.64 & \\
\hline & & & & & & $(0.391)$ & \\
\hline \multirow[t]{2}{*}{$\begin{array}{l}\text { Metallic Commodi- } \\
\text { ties Price Index }\end{array}$} & & & $-0.03^{* * *}$ & $-0.03^{* * *}$ & $-0.039^{* * *}$ & $-0.038^{* * *}$ & $-0.026^{* * *}$ \\
\hline & & & $(0.0023)$ & $(0.0023)$ & $(0.0036)$ & $(0.0039)$ & $(0.0026)$ \\
\hline \multirow[t]{2}{*}{ Seasonal Dummy 1} & & $9.14^{* * *}$ & $8.77^{* * *}$ & $8.77^{* * *}$ & $9.28^{* * *}$ & $8.74^{* * *}$ & \\
\hline & & $(1.09)$ & $(0.958)$ & $(0.946)$ & $(0.97)$ & (0.95) & \\
\hline \multirow[t]{2}{*}{ Seasonal Dummy 2} & & $4.3^{* * *}$ & $4.025^{* * *}$ & $4.0^{* * *}$ & $4.98^{* * *}$ & $4.57^{\star * *}$ & \\
\hline & & $(1.13)$ & (0.94) & $(0.941)$ & $(0.942)$ & $(0.9)$ & \\
\hline \multirow[t]{2}{*}{ Seasonal Dummy 3} & & $5.38^{* * *}$ & $5.09 * * *$ & $5.12^{* * *}$ & $5.93^{* * *}$ & $5.53^{* * *}$ & \\
\hline & & $(1.15)$ & (0.89) & $(0.89)$ & $(0.88)$ & $(0.85)$ & \\
\hline \multirow[t]{2}{*}{ Seasonal Dummy 4} & & $8.06^{* * *}$ & $8.46^{* * *}$ & $8.26^{* * *}$ & $9.17^{* * *}$ & $8.73^{* * *}$ & \\
\hline & & $(1.09)$ & (0.89) & $(0.91)$ & $(0.895)$ & $(0.87)$ & \\
\hline \multirow[t]{2}{*}{ Seasonal Dummy 5} & & $4.13^{* * *}$ & $4.08^{* * *}$ & $3.908^{* * *}$ & $4.89^{* * *}$ & $4.49^{* * *}$ & \\
\hline & & $(1.2)$ & (0.86) & $(0.86)$ & $(0.84)$ & $(0.81)$ & \\
\hline \multirow[t]{2}{*}{ Seasonal Dummy 6} & & $4.52^{* * *}$ & $4.49^{* * *}$ & $4.33^{* * *}$ & $5.08^{* * *}$ & $4.71^{* * *}$ & \\
\hline & & $(1.15)$ & (0.89) & $(0.88)$ & $(0.875)$ & $(0.82)$ & \\
\hline \multirow[t]{2}{*}{ Seasonal Dummy 7} & & $4.42^{* * *}$ & $3.99 * * *$ & $3.88^{* * *}$ & $4.56^{* * *}$ & $4.21^{* * *}$ & \\
\hline & & $(1.12)$ & $(0.85)$ & $(0.85)$ & $(0.85)$ & $(0.82)$ & \\
\hline \multirow[t]{2}{*}{ Seasonal Dummy 8} & & $4.27^{* * *}$ & $3.99^{* * *}$ & $3.79^{* * *}$ & $4.78^{* * *}$ & $4.45^{* * *}$ & \\
\hline & & $(1.08)$ & $(0.88)$ & $(0.88)$ & $(0.866)$ & $(0.82)$ & \\
\hline \multirow[t]{3}{*}{ Seasonal Dummy 9} & & $3.91^{*}$ & $3.21^{* * *}$ & $3.01 * * *$ & $4.0^{* * *}$ & $3.57^{* * *}$ & \\
\hline & & $(1.34)$ & (0.93) & $(0.9)$ & $(0.96)$ & $(0.94)$ & \\
\hline & & & & & & & (Continu \\
\hline
\end{tabular}


Discussion

Paper

Fiscal Fatigue and Public Debt Limit in Brazil: are we on sustainable path?

\begin{tabular}{|c|c|c|c|c|c|c|c|}
\hline & Model 1 & Model 2 & Model 3 & Model 4 & Model 5 & Model 6 & Model 7 \\
\hline \multirow[t]{2}{*}{ Seasonal Dummy 10} & & $6.22^{* * *}$ & $5.96^{* * *}$ & $5.86^{* * *}$ & $6.59^{* * *}$ & $6.24^{* * *}$ & \\
\hline & & (1.14) & (0.88) & $(0.89)$ & $(0.88)$ & $(0.86)$ & \\
\hline \multirow[t]{2}{*}{ Seasonal Dummy 11} & & $3.88^{* *}$ & $3.54^{* * *}$ & $3.46^{* * *}$ & $4.27^{* * *}$ & $4.02^{* * *}$ & \\
\hline & & (1.1) & $(0.86)$ & $(0.86)$ & $(0.84)$ & $(0.81)$ & \\
\hline $\mathrm{R}^{2}$ & 0.047 & 0.445 & 0.746 & 0.748 & 0.745 & 0.75 & 0.508 \\
\hline $\begin{array}{l}\text { ADF test of residuals } \\
\text { (t stat) }\end{array}$ & -0.739 & -0.988 & $-3.486^{* * *}$ & $-3.409^{* *}$ & $-3.474^{* * *}$ & $-3.699 * * *$ & $-3.959^{* * *}$ \\
\hline
\end{tabular}

The estimated fiscal functions in table 2 can be summarized as follows. Models 1 and 2 produce an inverse U-shaped reaction function, based on second order polynomials, close to the form observed in graph 4 . Models 3 and 7 produce similar flatter versions of those curves. Models 6 and 7 produce similar S-shaped curves based on third order polynomials. The estimated coefficients of other controls included in the models are mostly in line with previous studies. The coefficient for the output-gap around the 0.5 mark, and the coefficient for the IMF Dummy around -1.2, -1.3, are very close to the ones found by Ghosh et al. (2013) for their sample of advanced economies. The negative coefficient of the IMF dummy may sound counter-intuitive, since IMF loans usually come with the imposition of tight fiscal policies. On the other hand countries under an IMF agreement tend to have worse primary balances in the first place. Also in line with Ghosh et al. (2013), I find positive coefficients for trade openness, suggesting that the more open the economy is, the better tends to be its fiscal performance.

\section{DEBT LIMIT}

Where exactly is Brazil's debt limit? Which level of debt/GDP ratio represents the tipping point in which the dynamics of the debt turns explosive, and a sovereign default becomes the only alternative? What is the space for fiscal maneuvers still available before that debt limit is reached? In a scenario of fast fiscal deterioration, the knowledge of these things is a crucial element for Brazilian policy makers. This section provides estimates for the debt limit in Brazil, based on the fiscal reaction functions of section 4 , and plausible combinations of economic growth and interest rates. 
Graph 6 displays the fiscal functions estimated in models 1, 3 and 5. The points where the line $(r-g) d$ intersect these curves are the estimated equilibrium. The first intersection, with lower debt ratios, is the long-run debt-GDP ratio to which the country's public debt converges. The second intersection is the debt limit. The solid line in the graph is drawn for a real interest rate of 2.5 per cent per year, and a growth rate of output of 1 per cent per year. That scenario of low growth and moderate interest rates prevailed in the Brazilian economy in the last few years. I also consider in the graph a different scenario, perhaps the most likely outcome for the years ahead, with moderate growth, and low interest rates. The dotted line represents an annual growth rate of the economy of 2.2 percent, and an interest rate of 1 percent. Qualitatively, effects are the same for all the three models: an increase in the debt limit, and a decrease of the equilibrium with low debt, which is the long-run convergence point.

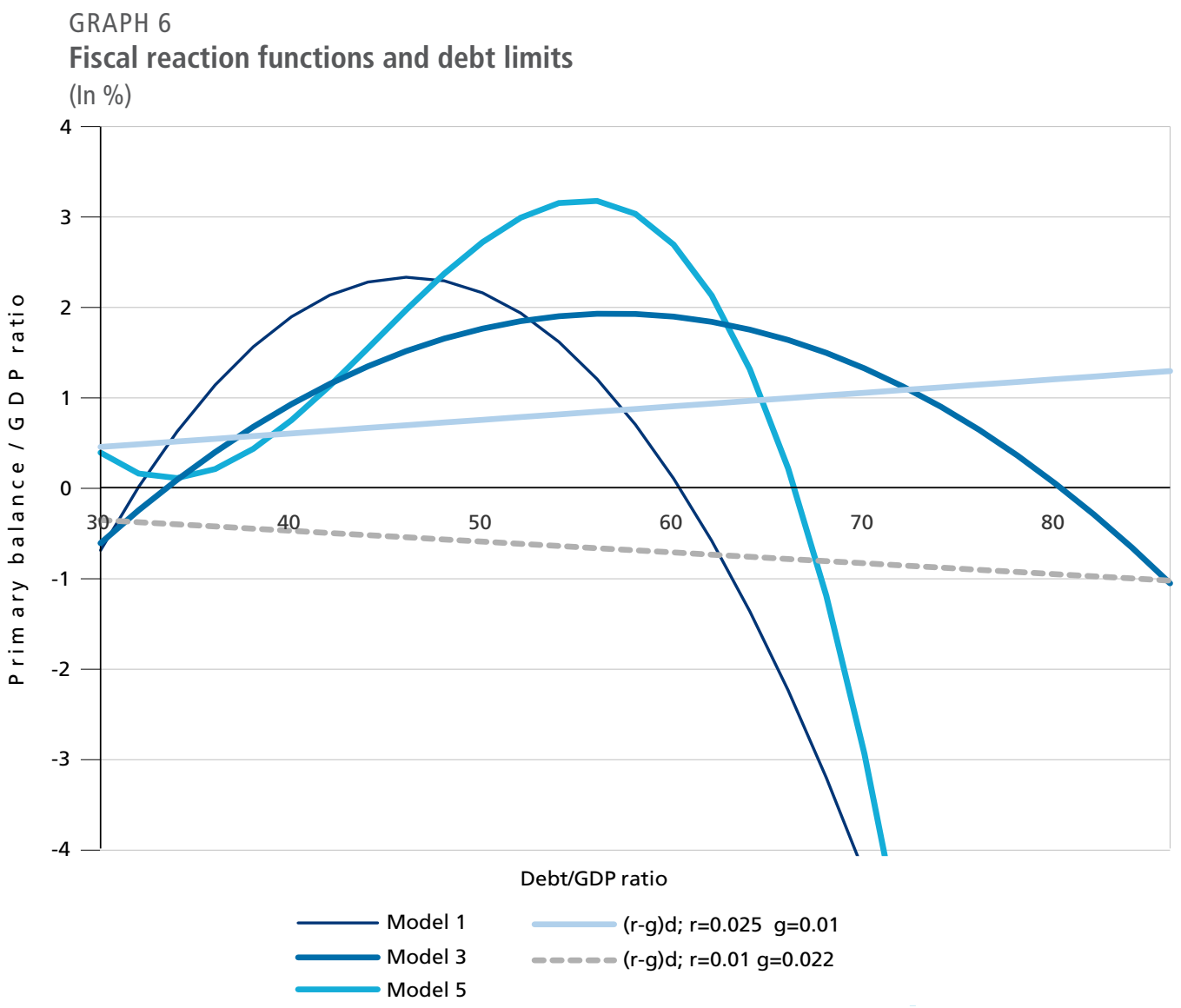

Author's elaboration. 


\section{Discussion}

Paper

Table 3 shows the calculated debt limits and stable equilibrium for the three models depicted in graph 6. It considers four different scenarios. The two that are represented by the straight lines in graph 6 (low growth, moderate interest rate; moderate growth, low interest rate), and two a bit more extreme. A high interest rate and moderate growth setting, reminiscent of what was happening in the Brazilian economy in part of the 90's, 2000 's, and 2010's. And a moderate interest rate and high economic growth. The higher the interest rates and the lower the economic growth, the more stringent the limit will be. Model 5 has the highest sensitivity of the debt limit to variations in the interest rate - economic growth differential. The debt limits estimated for Brazil in table 3 are considerably lower than the 150 to 250 percent range found for advanced economies by Ghosh et al. (2013). Why Brazil has such low limits of public debt is a question that deserves to be explored. It is symptomatic of an economy with a rogue fiscal past, and a long history of sovereign defaults dating back to the XIX century. 


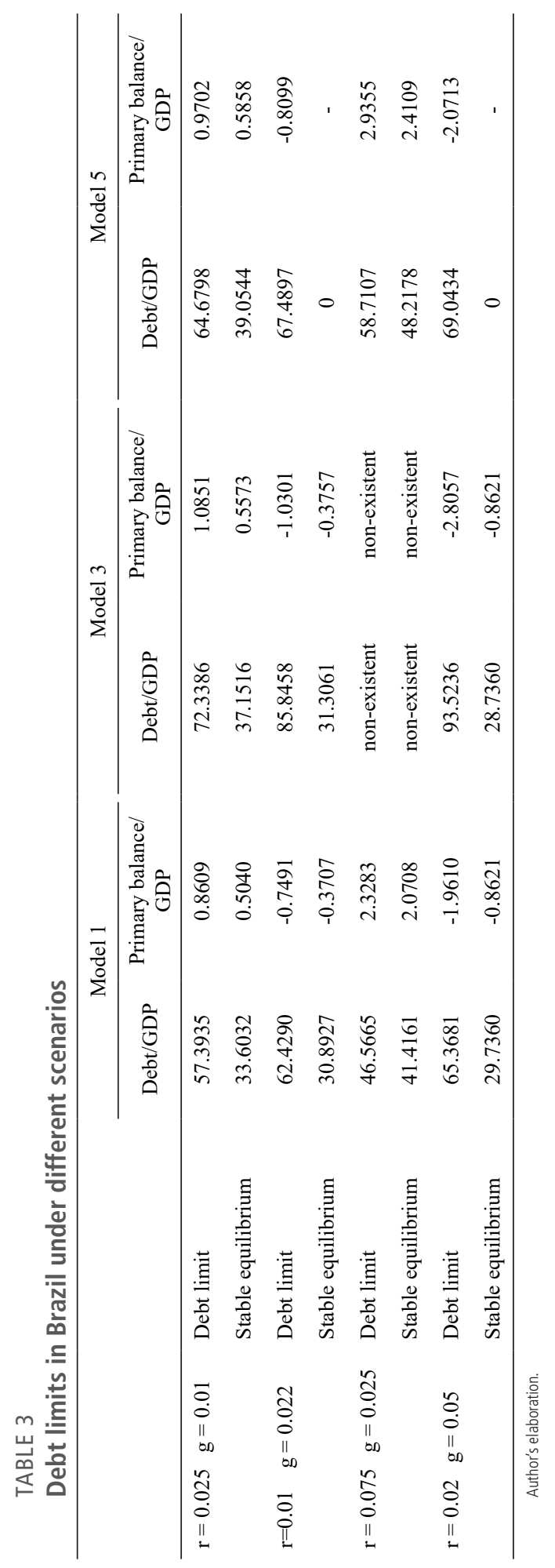

24 


\section{CONCLUSION}

As 2020 begins, Brazil is going through a major fiscal crisis in which the final outcome is still highly uncertain. In just five years the public debt as a ratio of GDP doubled, and policymakers have been unable to produce the hefty primary balances necessary to reverse the situation. To make things worse, a large recession hit the economy in 2015/2016, and solid economic growth still seems a distant reality. With all these setbacks, fiscal sustainability emerged once again as an important theme among economists in Brazil.

This paper contributes to the debate by introducing relatively new concepts - fiscal fatigue, fiscal space, debt limit - to an econometric model with Brazilian fiscal data. I estimate fiscal reaction functions relating primary balances and lagged debt, allowing for the possibility of non-linearities. The evidence presented in the paper suggests that fiscal fatigue takes place in Brazil at relatively moderate debt/GDP ratios (between 30 and 40 percent). Moreover, the debt limits estimated for the Brazilian economy are somewhere in between 60 and 80 percent of GDP, depending on the econometric specification, future economic growth and future interest rates. These magnitudes for the debt limit are remarkably low if compared the debt limits between 150 and 250 percent of GDP found by Ghosh at al. (2013) for a number of advanced economies. Considering that the current debt/GDP ratio observed in Brazil is in the high 50's, and on the rise, these findings should turn a red light to Brazilian policymakers. They make apparent that fiscal collapse looms just around the corner. The country cannot afford a prolonged fiscal imbalance, under the penalty of becoming insolvent, and having to face all the social and economic costs of a default of the sovereign debt.

\section{REFERENCES}

BOHN, H. The behaviour of US public debt and deficits. The Quarterly Journal of Economics, v. 113, n. 3, p. 949-963, 1998.

Are stationarity and cointegration restrictions really necessary for the intertemporal budget constraint? Journal of Monetary Economics, v. 54, n. 7, p. 1837-1847, 2007.

The sustainability of fiscal policy in the United States. In: NECK, R.; STURM, J.-E. (Eds.). Sustainability of public debt. Cambridge, United States: MIT Press, 2008. p. 15-49. 
CAMPOS, E.; CYSNE, R. A time-varying fiscal reaction function for Brazil. Estudos Econômicos, v. 49, n. 1, p. 5-38, 2019.

GHOSH, A. et al. Fiscal fatigue, fiscal space and debt sustainability in advanced economies. The Economic Journal, v. 123, p. F4-F30, 2013.

HAMILTON, J.; FLAVIN, M. On the limitations of government borrowing: a framework for empirical testing. The American Economic Review, v. 76, n. 4, p. 808-819, 1986.

ISSLER, J.; LIMA, L. Public debt sustainability and endogenous seigniorage in Brazil: time series evidence from 1947-1992. Journal of Development Economics, v. 62, p. 131-147, 2000.

LUPORINI, V. Sustainability of the Brazilian fiscal policy and central bank independence. Revista Brasileira de Economia, Rio de Janeiro, v. 54, n. 2, 2000.

Sustainability of Brazilian fiscal policy, once again: corrective policy response over time. Estudos Econômicos, São Paulo, v. 45, n. 2, p. 437-458, 2015.

MENDONÇA, M.; SANTOS, C.; SACHSIDA, A. Revisitando a função de reação fiscal no Brasil pós-Real: uma abordagem de mudanças de regime. Estudos Econômicos, São Paulo, v. 39, n. 4, p. 873-894, 2009.

MENDOZA, E.; OSTRY, J. International evidence on fiscal solvency: is fiscal policy "responsible"? Journal of Monetary Economics, v. 55, n. 6, p. 1081-1093, 2008.

SIMONASSI, A. Reaçáo fiscal sob mudanças estruturais e a solvência da economia brasileira. Fortaleza: Caen/UFC, 2013. Mimeografado.

TANNER, E. Intertemporal solvency and indexed debt: evidence from Brazil, 1976-1991. Journal of International Money and Finance, v. 14, n. 4, p. 549-573, 1995.

TREHAN, B.; WALSH, C. Common trends, the government budget constraint, and revenue smoothing. Journal of Economic Dynamics and Control, v. 12, p. 425-444, 1988.

- Testing intertemporal budget constraints: theory and applications to U.S. federal budget and current account deficits. Journal of Money, Credit and Banking, v. 23, n. 2, p. 210-223, 1991. 


\section{Discussion}

Paper

\section{APPENDIX A}

This appendix is about the data used in the paper. I take monthly data for the Brazilian economy from January of 1998 until August of 2019. I use the data for the primary balance of the general government, provided by Brazil's Central Bank. It aggregates the primary balances of the central government (national treasury, central bank, and the national pension system), and the states and municipalities. I use the "above the line" concept, in which the balance is just the difference between revenues and expenditures. It is divided by the monthly GDP, resulting in the primary balance as a share of GDP.

There are many different concepts of public debt in Brazil: gross and net debt, central and general government, central bank debts, states and municipalities' debts, state firms' debt, etc. I use the concept that allow Brazilian data to be comparable with other countries, namely, the net debt of the general government, as provided by the Central Bank of Brazil. This debt is defined as the net debt (debts less credits) of the federal government (including the social security system), of the state and municipal governments, with the private and public financial sectors, private non-financial sector, and international lenders.

Because the debt/GDP ratio is a ratio between a stock and a flow variable, the periodicity of the data matters. The standard practice is to report debt as a share of annual GDP. In order to make my monthly data comparable with that practice, there are two alternatives: $i$ ) take the debt, divide it by the monthly GDP and multiply it by 12; ii) take the debt, divide it by the accumulated last 12 months of monthly GDP. The two series turn out to be very similar, but option (ii) has less seasonal variations, and therefore was the chosen alternative.

A number of other independent variables are also included in the regressions, namely, inflation, commodity price variation, trade openness, the share of earmarked expenditures, and a couple of dummy variables, an IMF dummy and a dummy for the Nova Matriz Econômica (New Economic Matrix). Inflation is based on Brazil's consumer price index, the IPCA (Índice de Preço ao Consumidor Amplo). I use a standard measure of trade openness, namely the sum of exports and imports, divided by GDP. Since exports and imports are reported in US dollars, I convert them to Brazilian real using the end of period exchange rate, the buyer's rate. For the output gap, the official 
Brazilian data is available only as quarterly data. I use a monthly approximation that is calculated by Ipea’s (Instituto de Pesquisa Econômica Aplicada) Carta de Conjuntura.

The trickiest variable in our data set is the share of non-earmarked expenditures. Brazil's National Treasury Department used to report the government expenditures as the sum of four major categories: $i$ ) social security benefits, $i$ i) personnel and payroll taxes, iii) other mandatory outlays, and $i v$ ) outlays subject to financial budgeting. The first three categories are mandatory (earmarked), whereas the fourth is discretionary. However, a portion of these outlays subject to financial budgeting are actually earmarked, due to a number of Brazilian budgetary idiosyncrasies. Namely, laws defining minimum shares of expenditures in public health and education; the Bolsa Familia (Family Allowance) transfer program; and some payroll benefits to civil servants. So, (iv) divided by the total amount of outlays is actually an overestimation of the share of non-earmarked expenditures. The National Treasury realized that problem and in January of 2010 started to split category (iv) into two subcategories: (iv.1) mandatory with cash flow control; (iv.2) discretionary. I use that data, from 2010:01 to 2019:08. The question is how to get an estimate for the period in our analysis in which this data is not available (from 1998:01 to 2009:12)? I chose to calculate the average difference between (iv)/total outlays, and (iv.1)/total outlays for the period 2010:01-2019:08, and subtract that number from the series of $(i v) /$ total outlays. ${ }^{1}$ I then just stack these estimates from 1998:01 to 2009:12 with the observed data from 2010:10 to 2019:08, forming the complete series.

The IMF dummy variable has a unitary value for periods in which Brazil was under IMF support, and zero otherwise. Brazil took an IMF loan in December of 1998, and had it fully paid by February 2006. For every other period in our sample, there was no IMF interference in the country's budgetary affairs, so the dummy is set to zero. The Nova Matriz Economica was a major change in economic policy that took place mostly under Dilma Rousseff's administration, between 2011 and 2016. On the budgetary side that new policy deliberately increased expenditures, and introduced a number of tax exemptions. I consider that the Nova Matriz Economica policy begins when Rousseff took office in January of 2011, and ends when she was impeached in May of 2016. So the dummy variable has a unitary value throughout this period, and zero otherwise.

$\overline{\text { 1. Total outlays are }(i)+(i i)}+($ iii $)+($ iv $)+$ the total transfers related to revenue sharing. 

Ipea - Institute for Applied Economic Research

Press and Communications Office

\section{PUBLISHING DEPARTMENT}

\section{Coordination}

Reginaldo da Silva Domingos

Coordination Assistant

Rafael Augusto Ferreira Cardoso

\section{Supervision}

Camilla de Miranda Mariath Gomes

Everson da Silva Moura

\section{Typesetting}

Aeromilson Trajano de Mesquita

Cristiano Ferreira de Araújo

Danilo Leite de Macedo Tavares

Herllyson da Silva Souza

Jeovah Herculano Szervinsk Junior

Leonardo Hideki Higa

\section{Cover design}

Danielle de Oliveira Ayres

Flaviane Dias de Sant'ana

\section{Graphic design}

Renato Rodrigues Buenos

The manuscripts in languages other than Portuguese published herein have not been proofread.

\section{Ipea Bookstore}

SBS - Quadra 1 - Bloco J - Ed. BNDES, Térreo

70076-900 - Brasília - DF - Brazil

Tel.: + 55 (61) 20265336

Email: livraria@ipea.gov.br 

Composed in Adobe Garamond 11/13.2 (text)

Frutiger 47 (headings, graphs and tables)

Brasilia - DF - Brazil 

Ipea's mission

Enhance public policies that are essential to Brazilian development

by producing and disseminating knowledge and by advising

the state in its strategic decisions.

\section{ipea \\ Economic Research}

MINISTRY OF

ECONOMY
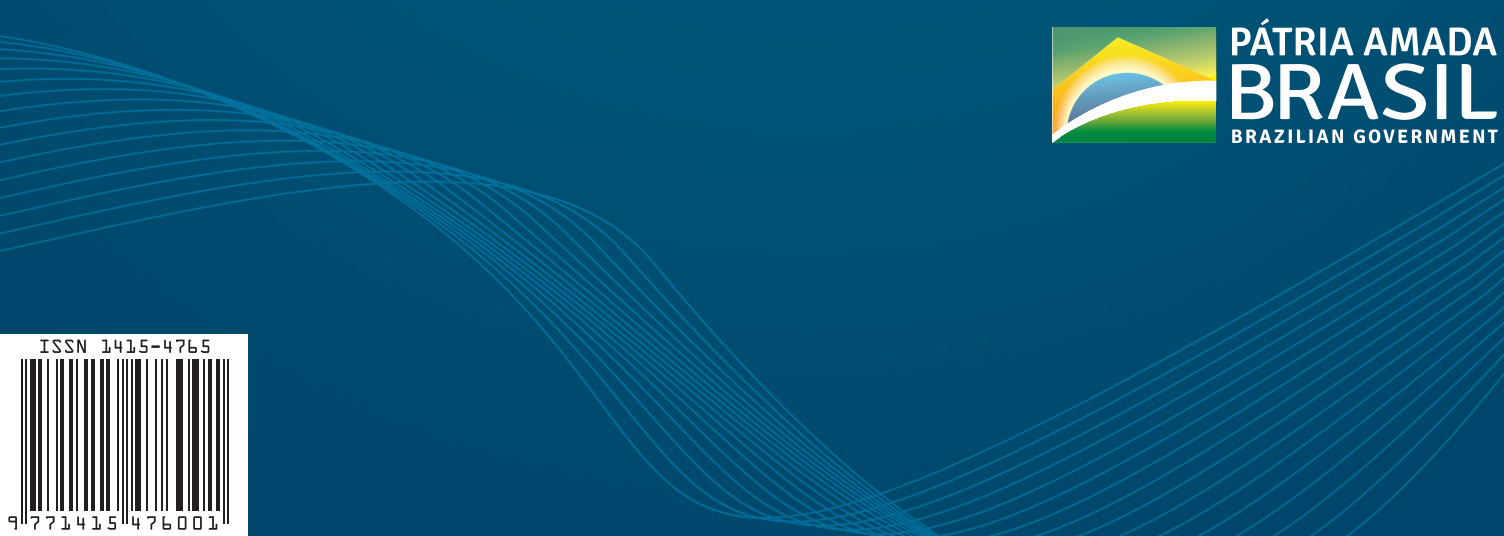